\title{
Anthropologists as Experts: Cultural Expertise, Colonialism, and Positionality
}

\author{
Livia Holden
}

This article addresses the positionality of anthropologists and the impact of anthropological theories in cultural expertise with the help of three case studies that highlight the engagement of anthropologists with law and governance during colonialism and in the wake of it: a well-known case of witchcraft in Kenya, Volkekunde theories in Africa, and the Rwandan genocide. The article starts with a short genesis of the concept of cultural expertise and its cognate concepts of culturally motivated crimes and cultural defense, to introduce the main question of this article: What can we learn from the use of cultural expertise in the colonial past? Today, as much as in the colonial past, anthropologists have been torn between action and abstention. The article's three case studies show that neither action nor abstention is free from ethical responsibility. This article argues that the concept of procedural neutrality and its reformulation in the form of critical affirmation help anthropologists to carve out an independent role for themselves in the legal process. Procedural neutrality and its reformulation as critical affirmation make it possible to comply with the ethics and deontologies of the disciplines across which anthropologists operate when providing cultural expertise.

\section{INTRODUCTION}

The recent history of legal anthropology and sociolegal studies shows a persistent yet specialized interest in the relationship between law and culture within and beyond positive law. Whilst the engagement of anthropologists and sociolegal scientists with law in the role of expert witnesses has been concomitant with the academic interest in law and society since at least the eighteenth century, this engagement was conceptualized only toward the end of the twentieth century with the consolidation

Livia Holden (Director of Research Paris Nanterre, Full Professor at the University of Padua) leads two European Research Council-funded projects: Cultural Expertise in Europe: What Is It Useful for? (EURO-EXPERT) and CULTEXP: the first multilingual and cross-jurisdictional database on cultural expertise (CULTEXP). She has provided expert opinions for cases pertaining to immigration law, family law, and criminal law in the United Kingdom, United States and the Netherlands. Prior to Paris Nanterre, she was Senior Research Fellow at the University of Oxford, and SCR Member and College Advisor at St Antony's College; Dean of the Humanities and Social Sciences Faculty and Professor of Anthropology at the Karakoram International University; Associate Professor of Anthropology at Lahore University of Management Sciences; Lecturer in International Human Rights and Research Fellow at the Socio-Legal Research Centre at Griffith University; Research Fellow at Freie University; and Visiting Lecturer at Humboldt University Berlin and INALCO Paris. She was 2015/16 Fellow at the Institute for Advanced Studies in Nantes, recipient of the 2016 Social Sciences Award from the Pakistan Inter-University Consortium for the Promotion of Social Sciences, and in 2021 she was nominated Outstanding Woman and Academic by the Swiss National Foundation.

I thank Marius Holden, anthropologist and ethnographic filmmaker, for his advice and feedback at all stages of the development of this article. 
of the concept of cultural defense in the North American context. Cultural expertise was envisioned in 2009 as "the special knowledge that enables socio-legal scholars, or, more generally speaking, cultural mediators-the so-called cultural brokers-to locate and describe relevant facts in light of the particular background of the claimants and litigants and for the use of the court" (Holden 2011, 2). In 2019 the concept of cultural expertise was further expanded as an umbrella concept that includes all kinds of use of social sciences knowledge by social scientists for the resolution of conflicts and the ascertainment of rights in court and out of court (Holden 2019). However, until the conceptualization of cultural expertise in 2009 and its expansion as an umbrella concept in 2019, the focus was more on the relationship between law and culture and less on the ways anthropologists engage with the legal process as well as with claims or ascertainment of rights and conflict resolution. As I have outlined elsewhere in a short historical survey of cultural expertise (Holden 2020), many instances of involvement of social scientists with law have at some point been problematic. Whilst cultural expertise as an umbrella concept concerns the involvement of all kinds of social scientists with law, this article will focus on the involvement of anthropologists, which has already met with criticism and skepticism from within the discipline of anthropology. A significant reason for self-scrutiny in the engagement of anthropologists with law and governance has been the dubious and unethical linkage of certain anthropological trends and certain anthropologists with dominant powers during colonialism. However, whilst ethical guidelines were strenghtened, some anthropologists have opted for nonengagement. Yet, the consequences of nonengagement as expert witnesses in situations of conflict and litigation may sometimes outweigh the risks involved in engagement because anthropologists may be, in certan situations, the best suited to contribute to the protection of vulnerable groups and individuals. This article acknowledges the historical complicity of anthropology with the colonial agenda and looks in depth at the modalities of this complicity to assess whether the cause was the lack of independence of anthropologists or, rather, specific anthropological theories that conflicted with the ethical tenets of the discipline or, more generally, the incommensurability of anthropology with law and governance.

This article offers, first of all, a short excursus on the genesis of the concept of cultural expertise to illustrate the link between older and newer practices of cultural expertise. It then steps back in time to investigate the engagement of anthropologists with the legal system at the time of colonialism and in the wake of it. It combines, on the one hand, a historiographical perspective of the twenty-first century according to which new interdisciplinarities are needed to understand Western legal history, and, on the other hand, the pragmatic approaches of new legal pluralism which have placed value on non-European laws whilst positioning critically against colonialism. This article does not claim to be exhaustive but relies on the analysis of selected cases and, unfortunately, tragic events that have marked the history of anthropology so as to identify an ethical framework for the engagement of anthropologists with law and governance today: Bronisław Malinowski and indirect rule in Africa regarding Rex $v$. Kumwaka s/o of Mulumbi and 69 Others; the use of Volkekunde theories to support apartheid in South Africa; and the potential responsibility of Dutch and Belgian anthropology vis-à-vis the Rwandan genocide. In all these matters, anthropologists provided knowledge and theories that were used for the resolution of disputes and 
the appraisal of rights for a certain social group in a process that I identify as cultural expertise. However, either the involvement of those anthropologists with law and governance, or the theories that were generated as a result, have been the object of criticism both within and outside the discipline of anthropology. Therefore, it is crucial to position today's cultural expertise with regard to the involvement of anthropologists with law and governance during colonialism: Was it the inappropriateness of anthropological knowledge per se in the applied context of law and governance, or were rather the modalities of the transmission of this knowledge that led some of these endeavors to fail? And what are the implications for anthropologists today in their engagement with cultural expertise?

The history of anthropology has already examined the responsibility of some anthropologists, but there is, as yet, no settled view on the positionality of cultural expertise during colonialism, because the conceptualization of cultural expertise itself is recent. By adopting cultural expertise as a new conceptual framework for documented practices for the engagement of anthropologists with law and governance, this article proposes a reassessment of these practices against the backdrop of the deontological tenets of anthropology, with the aim of providing new reference points for responsible engagement in today's practice of legal anthropology. Clearly, cultural expertise, as with any form of expertise, is not special knowledge per se. Cultural expertise as special knowledge is necessarily not absolute but relative to the context in which it is deployed. Anthropologists can be experts in some contexts of litigation and the ascertainment of rights because they can communicate knowledge with which the decision-making authorities are not familiar. Hence, the importance of considering the positionality of the anthropologists providing cultural expertise; in other words, the awareness of the sociopolitical context in which cultural expertise is deployed and received.

This article does not dispute criticisms that have been levelled against the unethical engagement of some anthropologists with the legal process, because the implicit or explicit endorsement of discriminatory policies is abhorrent. However, an unwanted consequence was the widespread refusal of anthropologists to engage with the legal process at all, which risks perpetuating equivalent discrimination and abhorrent practices today. Hence, I suggest that the focus should be shifted from the opportunity for engagement to the modalities of engagement, so as to strengthen the ethics of cultural expertise and ensure that it is provided at the service of a fairer and more inclusive justice system, especially as regards minorities and vulnerable groups.

\section{CULTURALLY MOTIVATED CRIMES, CULTURAL DEFENSE, AND CULTURAL EXPERTISE}

Although I have outlined elsewhere the genesis of the concept of cultural expertise and its position vis-à-vis cognate concepts in sociolegal studies and the anthropology of law, a short excursus is necessary here as well, to provide an explicit conceptual framework for my exposition. Hence, in this section I will mention the concepts of culturally motivated crimes, cultural defense and cultural expertise.

Strijbosch (1991) stressed the moral conflict between majorities and minorities, arguing that cultural references are multiple and diverse. With the notion of culturally 
motivated crimes, Strijbosch pointed to the potential conflict between the principles of the majorities and those of minority groups. The conceptualization proposed by Strijbosch was broader than the categorization of culturally motivated crimes, which ensued and established a link between a new category of crimes and ethnic minorities. Strijbosch's focus was more on the moral conflict engendered by the confrontation among diverse cultural references and less on the creation of categories of crime. After Strijbosch, various definitions of culturally motivated crimes were proposed by the sociolegal literature in connection with the notion of cultural defense. Thus, for Van Broek, a culturally motivated crime is "an act by a member of a minority group or culture, which is considered an offence by the legal system of the dominant culture. That same act is nevertheless, within the cultural group of the offender, condoned, accepted as normal behaviour and approved or even endorsed and promoted in the given situation" (Van Broeck 2001). Van Broeck shifted the focus from the moral conflict to criminal responsibility but left the door open for debate on the moral conflict of the perpetrators of culturally motivated crimes. Whilst suggesting a causal link between culture and criminal responsibility, Van Broeck emphasized the moral struggle between the principles of the majority and the principles of the minority to which the perpetrators of culturally motivated crimes belong.

Renteln's The Cultural Defense offers one of the most complete overviews to date of the potential application of the concept of culturally motivated crimes in both the criminal and civil processes (Renteln 2004). Renteln's position is that the cultural defense, which may diminish criminal and civil responsibility in the presence of cultural arguments (ibid., 5-7), responds to the need to redress the structural inequality of the judicial system, which is otherwise ill-equipped to ensure a substantially equal application of the law to all citizens (ibid., 187). She stretches the notion of cultural defense beyond criminal law, arguing that cultural defense should not only function as a partial excuse when cultural motives are admissible in the penal process (ibid., 191) but should also influence decision making in civil litigation so as to allow certain exemptions where it is found that there is a specific cultural background to the facts (ibid., $201 \mathrm{ff}$ ).

Multicultural Jurisprudence: Comparative Perspective on the Cultural Defense, edited by Renteln and Foblets (2009), shows that the cultural defense has the potential to extend beyond the conventional conceptualization of the defense in criminal law in North America, and may support a more informed decision-making process. Woodman (2009) argues that the scope of multicultural jurisprudence is greater than the legal conceptualization of the cultural defense. Renteln and Foblets (2009), in their conclusions to the volume, list not only the subfields of law in which cultural arguments have a de facto role, including immigration law, family law, and labor law, but also the concerns that cultural defense has generated amongst sociolegal scholars. These include the potential misuse of the cultural defense, the danger of reinforcing stereotypes of minorities, and the risk of enforcing a notion of cultural determinism. Hence, Renteln and Foblets (2009) reformulated and shifted the target of cultural defense from providing a partial excuse for the defendant to, rather, supplying better information to the court, which nevertheless remains free to decide.

In North America, cultural defense has received significant attention and implementation, generating also a substantial body of sociolegal scholarship. In Europe, the concept of culturally motivated crimes and cultural defense resonated 
with the necessity to take into consideration social diversity. However, sociolegal scholars have found both concepts difficult to handle, especially in civil law legal systems because of uncertainties over what constitute culturally motivated crimes (see, among others, Basile 2011). The concept of culturally motivated crimes and cultural defense has given rise to assessments on the appropriateness of introducing a sociocultural classification of crimes into the legal process. Visweswaran (2010) argues that in the use of cultural arguments in connection with minorities there is a danger of the substitution of the notion of culture with that of race, thereby stigmatizing vulnerable groups despite the intention to protect them. Whilst both concepts of culturally motivated crimes and cultural defense were born out of an attempt to redress the structural imbalances of the legal systems, concerns have also been formulated about their potential for stigmatization of the social groups to which the perpetrators of culturally motivated crimes belong.

The concept of cultural expertise proposes a broader and more encompassing conceptual framework that includes but is not limited to cultural defense and revolves especially around the positionality of the experts. Cultural expertise is applicable to a wider range of legal fields and legal systems than cultural defense because it is not connected with the position of the defense. I propose cultural expertise as procedurally neutral, allowing a clearer positioning of social scientists vis-à-vis their own professional ethics whilst also abiding by the requirements of the legal process. From the legal point of view, cultural expertise is not different from any other kind of expertise in any field that goes beyond the experience of the courts. Hence, cultural expertise does not require any change in the law, but an awareness of the benefits that cultural knowledge could bring to the legal process.

I have shown elsewhere that in native land title disputes in America, the appointment of anthropologists and social activists as experts dates to the nineteenth century (Holden 2020). Recent migration flows and a greater awareness of diversity in Europe have reignited the need to understand the cultural backgrounds to facts, primarily in matters of international protection but also in criminal law, family law, and labor law, whenever the courts are not familiar with the sociocultural background of facts and people. Common law countries have instructed anthropologists as "country experts," whilst civil law countries have been more reluctant. There, the legal professions have often taken it upon themselves to provide cultural knowledge wherever necessary (Bartoli 2014; Ciccozzi and Decarli 2019). Experiments such as a cultural test for judges have also been proposed to address the appraisal of culture by the judges themselves and without the systematic appointment of experts (Ruggiu 2019).

When the concept of cultural expertise was defined for the first time in 2009, it was also theoretically positioned with regard to the concept of cultural defense and multicultural jurisprudence to elucidate the epistemological similarities and differentiate between the above concepts. The EURO-EXPERT team has formulated a new integrated definition of cultural expertise, which is defined as special knowledge that enables social scientists, such as sociolegal scholars, historians, experts in laws and cultures, and cultural mediators-the so-called cultural brokers-as well as ethnopsychologists and ethno-psychiatrists, sometimes also members of the legal professions, to locate and describe relevant facts in light of the particular background of the 
claimants, litigants, defendants, and plaintiffs, for the use of the decision-making authority. ${ }^{1}$ The initial format of the definition is retained but the field and the modalities are broadened to include a greater variety of professionals, sometimes the legal professionals themselves, and making room for out-of-court contexts.

The above integrated definition of cultural expertise considers not only the evolution and development of the notion of cultural defense and multicultural jurisprudence but also the broader application of cultural arguments irrespective of the defense. Thus, cultural expertise is neither limited to recent migration nor confined to Europe or in-court conflicts. Cultural expertise is proposed as an umbrella concept that includes cultural defense, but it also covers a broader range of engagement toward social diversity, and stresses the notion of special knowledge and ethical duty toward the decision-making authority. This article will also fine-tune the components of the concept of cultural expertise with regard to the notion of "special" knowledge which, similarly to other kinds of expertise, cannot but be relative; and regarding the duty of the expert to the decision-making authorities, which must not compromise the deontological tenets of anthropology.

Current research indicates that cultural expertise, with or without the appointment of experts, is routinely used in Europe, America, and Australia in an increasing range of cases in criminal and civil law, including many subfields of law. ${ }^{2}$ Nonexhaustive topics for cultural expertise include the validity of customary practices; the modalities of persecution based on ethnicity, sexuality, and faith; the risks of return to the country of origin for an asylum seeker; the kind of protection that persecuted individuals can hope for from the state against nonstate individuals and organizations; the efficacy of public and private health services; the implementation of legislation for the protection of vulnerable groups; customs and usage in family law and transnational entrepreneurship; terrorism and radicalization; transitional justice; and the implementation of treaties with First Nations. Cultural expertise plays a role not only in new forms of cultural diversity but also in what is termed "ethnic diversity," including First Nations and linguistic minorities that enjoy semi-autonomous rights sanctioned by treaties and constitutions. Cultural expertise is routinely applied also in societies that are perceived or perceive themselves as homogeneous, especially in cases related to hate speech and intellectual property. The broad spectrum of cultural expertise is connected with the fact that the contents of cultural expertise do not vary significantly across jurisdictions and fields of law. In fact, though some knowledge of law helps, it is arguable whether experts in any discipline need to understand the subtleties of procedural rules in the various jurisdictions and phases of the legal process. This means that a broad conceptualization of cultural expertise makes sense in the sociolegal sciences without, however, suggesting that this definition might be also a legal one. In the same vein, this article is not concerned with the potential influence of cultural expertise on the legal outcome, but instead on the positionality of cultural experts.

1. EURO-EXPERT is the acronym for Cultural Expertise in Europe: What Is It useful for?, a European Research Council project. See: https://culturalexpertise.net.

2. See, among others, Burdziej 2020; Ciccozzi and Decarli 2019; Cooke 2019; Lopes, Leão, and Ferro 2019; Marin 2020; and Rosen 2020. For an interactive map that visualises EURO-EXPERT's data on cultural expertise in court on out-of-court see https://culturalexpertise.net. 
Since the concept of cultural expertise is cross-disciplinary, cross-sectoral, and can be applied to a variety of engagements of social scientists with law and governance, the analysis has, potentially, a large sample. This article focuses on the recent history of cultural expertise in anthropology for two reasons: the availability of historical records of the involvement of anthropologists with law and governance during colonialism; and the self-examination that this involvement generated within the discipline of anthropology. In the 1960s, anthropology was accused of providing the theoretical models of colonial dominance (see Maquet 1964; Diamond 1964; and Diamond 1966) and racist discrimination (Jordan 1968; Memmi and Greenfeld 1967; Memmi 1969), and for being complicit with or not opposing colonial policies. The latter criticism, hinting at the opportunist attitude of some anthropologists, was developed by Asad (1973) who suggested that the privileged position of anthropologists, enjoying safe access to non-European cultures, was not accompanied by a rigorous criticism of the iniquities of colonial administrations. The following section peruses the modalities of the engagement of anthropologists with law in a few well-known cases in which anthropologists played a role or were accused of having played a role to the detriment of minorities or vulnerable groups, to learn from the past and envision an ethical use of anthropological knowledge in court for the benefit of substantial justice.

\section{Rex v. Kumwaka s/o of Mulumbi and 69 Others}

Rex v. Kumwaka s/o of Mulumbi and 69 Others was decided in 1932 in Kenya, which between 1920 and 1963 was part of the East Africa British Protectorate. A group of sixty men was sentenced to death for murdering a woman believed to be a witch who had cast a spell on one of the men's wives, rendering her mute (Luongo 2011). The case attracted attention in England and resonated with preoccupations of sovereignty in the first place, but the reasoning shared similarities with today's strategy of cultural defense and the notion of culturally motivated crimes. The colonizers of the early twentieth century became preoccupied with the following questions: should customary law apply in cases such as the murder of a witch and therefore should leniency be afforded; or should state law, in this case the law of England, remain sovereign in matters of penal law? Two experts were appointed. These were the Deputy and Provincial Commissioners in Kenya who quoted, in parallel, colonial law and the principles and practices of customary law in Kenya, arguing that their duty was to translate the practice into more familiar terms for the British Empire (Luongo 2011). Frederick Lugard, British soldier and colonial administrator, and Bronisław Malinowski, anthropologist, argued in public debates, respectively, against and for the application of customary law whilst both were in favor of indirect rule, which meant the governance of colonies through preexisting power structures deemed to be Indigenous.

Frederick Lugard was against the application of customary law for murder, arguing that the state law of England should apply, and had called for more funding for anthropology to address witch-killings in Africa. Bronisław Malinowski, who is widely known for his field methods and his specific interpretation of functionalism, was in favor of the application of customary law. Malinowski argued for a sort of collaboration between 
African and European institutions, creating the conditions for a domestic development of law in Africa on its own terms. According to Malinowski, whose approach was also categorized as jurisprudential indirect rule, magical beliefs would ensure social solidarity and should be seen as key components of customary law (Foks 2018). Therefore, any attempt to override customs was nothing other than a threat to the maintenance and reproduction of the social order of each particular community. As quoted by Foks, in a seminar at the London School of Economics, Malinowski forcefully expressed the need for social scientists to have a strong sense of ethical commitment (Malinowski 1933):

It is futile and a sign of mental laziness if the man [sic] of science pretends he can keep away from ethical questions or that he should not state it when his scientific outlook contributes to real welfare of humanity.

The reaction at the time of the public and the media in Africa and in England was in favor of a lenient sentence, which was eventually, albeit reluctantly, imposed. Yet, this article is not primarily concerned with the outcome of the case. Rather, it seeks to understand, retrospectively and for the sake of today's positionality of cultural expertise, what may have been the ethical and deontological dilemmas of anthropologists' engagement at that time.

We have here competing interpretations of culture: culture as potentially absolving the perpetrators from criminal responsibility and culture as a significant instrument for social cohesion, both leading to leniency toward the culprits yet subscribing to different interpretations of indirect rule. Lugard wanted to preserve the formal supremacy of state law, whereas Malinowski wanted to preserve the supposed inner harmony of the so-called traditional societies. Was Malinowski's stance nothing other than misplaced romanticism or, by pleading for the primacy of customary law, was he a forerunner of the formal post-war commitment to the anthropology of Indigenous rights?

Malinowski's professional ethics were scrutinized after the posthumous publication of his diary in 1967, in which he revealed controversial aspects of his personality and relationships with Indigenous people that cannot but be rejected today (Malinowski and Guterman 2004). According to Foks, however, Malinowski's specific brand of jurisprudential indirect rule contributed to somehow unsettling colonial ideology, and in particular the justification of the British Empire in its so-called civilizing mission that belittled non-European cultures (Foks 2018). Malinowski had without doubt benefited from Lugard's endorsement of anthropology in Africa. Its ideology and aims were diametrically opposite to today's ethics and deontology of anthropologists. However, retrospectively, analysis can go further and attempt to pinpoint the boundary between professional opportunism and engagement with what we could term today "societal problem solving."

As Foks shows, Malinowski's position was inherently ambiguous because of a mix of subjection to and complicity with power structures, yet he managed to maintain a stance which was at least mildly critical of colonialism. Such an ambiguity is relevant for today's engagement of anthropologists with law. In fact, anthropologists involved with law, either because of the different logics of law and anthropology or because of structural power imbalance between the legal and academic professions, have shown 
incapacity or awkwardness in dealing with political pressure (Colajanni 2014; Grillo 2016). Foks's scrutiny of Malinowski's involvement with law suggests, at first sight, the potential of a deeper incongruence related to Malinowski's endorsement of a specific model of governance as indirect rule. Foks argues that Malinowski managed to challenge an unjust system from within. This does not mean that Malinowski actually wanted to overturn colonial authority in any way, or that he was successful in doing so, but according to Foks, Malinowski, in spite of supporting indirect rule, at least attempted to position himself against what he considered to be unjust and argued for an ethical positioning. Whilst we assume that today anthropologists can afford more independence vis-à-vis state authorities, the analysis of Malinowski's positionality takes into consideration governance as another component of the positionality of the anthropologists engaging with law. In other words, it spotlights not only the then explicit subscription of certain anthropologists to colonialism but also their implicit complicity because they professionally benefitted from the endorsement of anthropology in Africa during colonial rule.

The Kenyan case shows that experts are potentially vulnerable to pressure from the legal profession and from political regimes that may try to coopt them for political reasons. In the case of Malinowski, it is uncertain whether the reasons behind his ambiguity merely rested in the lower status of anthropologists in comparison with colonial administrators and consequently their vulnerability to social opportunism, or whether his ambiguity was rooted more deeply in anthropological theories that supported discrimination through indirect rule. On the one hand, British officers claimed to protect customary law by not interfering with its administration, while on the other hand aspects of customary law that were perceived as offensive to British principles of justice were struck down by magistrates and judges. Foks (2018) insists that Malinowski challenged the colonial system of justice from inside by blurring the boundaries between those cases where the application of customary law did not present a challenge to the "civilizing mission" of colonial administrators, e.g., the adjudication of goat ownership, and those cases, like the killing of witches, which were instead, considered as incompatible with the administration of justice under British rule. Since magical beliefs represented a key element of customary law and ensured the social cohesion of the community, their dismissal, according to Malinowski's functionalist theory, would lead to social collapse.

It is beyond the scope of this article to establish whether the above reasoning exerted any pressure against the colonial regime or whether Malinowski himself was ever in a position to act more explicitly against colonial rule. However, the broader question for the purpose of this article is whether the vulnerability and consequent ambiguity of the positionality of anthropologists acting as experts is inherent in the procedural position of the expert or whether it is instead connected with the theories of anthropology? This is a crucial matter for today's cultural expertise because it touches both the modalities and the substance of the use of anthropological knowledge outside academia and in a problem-solving situation. Thus, this article will give an overview of the role of Volkekunde, an anthropological theory which helped to sustain apartheid in South Africa and provided the moral justification of genocide in Rwanda, although most anthropologists openly dissociated themselves from such theories. 


\section{VOLKEKUNDE AND STRUCTURAL FUNCTIONALISM IN SOUTH AFRICA}

South African Volkekunde is an example of the application of discriminatory practices based on anthropological scholarship which nonetheless attracted significant criticism from the onset. In fact, in South Africa at the time of apartheid (1948-1990s), a Marxist tradition of social anthropology, developed at several South African universities, which was explicitly opposed to the mainstream policies of discrimination (Hinton 2002). Social anthropologist David Webster at Witwatersrand University paid with his life for his involvement as a human rights activist against apartheid (James 2009). Yet, in spite of the fact that Volkekunde did not enjoy substantial credit among anthropologists, it asserted itself in South Africa and eventually provided scientific support for abhorrent practices of discrimination during the apartheid period. Toward the end of the twentieth century, when apartheid ended, Volkekunde was appropriated by underprivileged South African groups claiming the status of First People and connecting the very theory that had supported discrimination earlier to the claim of rights for South African First People. The appropriation of Volkekunde shows the multidimensional framework of social stigma, which can be appropriated and reversed against the oppressors. This article suggests, furthermore, that the reappropriation of Volkekunde also highlights the potential complexity of cultural expertise's positionality: in the case of Volkekunde the very theory that had supported discrimination becomes the flagship of cultural identity. Hence, in order to examine the influence of the social and political context on the role of potential cultural expertise, it is necessary to briefly overview the history of anthropology in South Africa.

The history of anthropological scholarship in South Africa is characterized by the presence of two distinct schools: the British structural functionalist school, which was established with the appointment in 1921 of Alfred Reginald Radcliffe-Brown as chair of social anthropology at the University of Cape Town; and the Afrikaans ethnology which was founded in the decade 1926/36 at Stellenbosch University by Werner Eiselen. Afrikaans ethnology, better known as Volkekunde, was influenced by the African linguistic studies of the German linguistic school of Carl Meinhof and, in contrast with the British structural functionalism, was based on classification rather than participant observation. Until the 1940s, there were sporadic contacts between scholars belonging to the two schools. However, the victory of the conservative National Party in South Africa led to the introduction in 1948 of segregationist policies known as apartheid. During the implementation of such abhorrent practices of segregation, many English-speaking anthropologists were forced into exile, thereby undermining the structural functionalist trends in South Africa.

Between 1948 and 1954, the National Party introduced a series of measures to reduce the influence of Great Britain in South Africa in order to lay the foundation for an independent Afrikaans Republic, and the preference accorded to Afrikaans over English as the medium for education was one of these measures (Johnson 1982). The application of Volkekunde, whose proponents were almost exclusively Afrikaans-speaking scholars, offered scientific support to apartheid policies meaning that, whilst formally fostering the original cultural features of native groups, in reality 
they sought to justify white domination over a large majority of Black people (Gordon 2018). Nonwhite South African citizens were barred from public functions since, according to the policies influenced by Volkekunde theories, the development of Black communities, in particular Bantu, should have been taking place exclusively within the sociocultural boundaries of their own cultures. Conversely, the Government of South Africa, which included the supervision of the Black community's affairs, was the responsibility of white Afrikaners (Seroto 2013).

The Volkekundiges (followers of Volkekunde) focused on racial and cultural differences based on the precolonial past and their essentialist theories relied on a diffusionist hypothesis of the intermixing of native Black people and members of the "Hamitic" race, who were reputed to be racially closer to white people (Gordon 1987). Whereas the followers of Radcliffe-Brown and Max Gluckman's structural functionalism viewed South Africa as one complex social system, according to the Volkekunde theory, also known as ethnos theory, South African society was a collection of irreconcilable racial entities. Incompatibility between members of different social groups, which was one of the tenets of Volkekunde, also affected ethnographic practices. Eiselen, a South African anthropologist and linguist, and his Volkekunde colleagues usually conducted short-term fieldwork where they collected artifacts and obtained texts through dictation, preferably from elder male subjects (Evans 1997). True to the principles of interracial segregation and to the classificatory aims of Volkekunde science, Volkekundiges avoided real-life engagement with living speakers in stark contrast with the Malinowskian method of participant observation followed by structural functionalist ethnographers (Bank 2015).

In the late 1960s, efforts to communicate across the two scholarly traditions of Volkekunde and structural functionalism failed against the backdrop of an increase in political radicalization in academia across South Africa. In 1977, Volkekundiges, who refused contact with Black anthropologists and used exclusively Afrikaans for publications and conferences, founded the Vereniging van Afrikaanse Volkekundiges (VAV) (Association of Afrikaans Anthropologists). Informal English-language conferences organized by the proponents of British anthropology continued but English-speaking anthropologists were outnumbered by their Volkekunde colleagues, who almost exclusively controlled departmental policies, curricula, access to teaching positions, and funds for anthropological research (Gordon 1988). Gordon observes that, in South Africa, the monopoly of anthropological knowledge was maintained by Afrikaansspeaking anthropologists who retained their hegemony by completely overshadowing their English-speaking colleagues until the 1990s (Gordon 1988).

In 1975, an ethnology department was set up to provide anthropological knowledge to the South African Defence Force (SADF) to quell and control insurgency and increasing civil unrest. The necessity to translate academic knowledge into practical know-how for the benefit of military personnel in the field favored the creation of oversimplified ethnographic manuals imbued with racist and misogynist advice (Gordon 1987). However, the military engagement with anthropologists was mitigated by the declared aims to "improve race relations" and the actualization of the WHAM program: "Winning the Hearts and Minds" of the Indigenous. This peaceful endeavor provided an ethical veneer for otherwise aggressive policies of mass control (Gordon 1987). 
There is little dispute on the historical connection of Volkekunde with apartheid in South Africa. In the late 1980s, the rise of anti-apartheid movements and the increasing global attention to the iniquities of South African policies coincided with the boycott of all academic institutions in South Africa by international academia. The end of apartheid took place in 1991 and, after the elections in 1994, South African anthropology experienced a change of paradigm which triggered transformations in the curricula and modified power relations at universities. Volkekunde departments decreased in number and influence because most young anthropologists rejected the ethnos theory. However, the history of Volkekunde does not end here.

At first sight, the criticism of the appropriation of anthropological knowledge by oppressive power structures and, at the same time, the suppression of the Volkekunde ethnographic program, is perfectly consistent with the ethics of anthropology. However, the landscape of potential sources of anthropological knowledge in South Africa diversified further when at the end of twentieth century, post-apartheid phenomena of cultural identification gave rise to essentialist claims of "tribes," and First People appropriated Volkekunde (Waal and Ward 2006). The expression "essentialism from below" uttered at the introductory speech of the 2004 Anthropology Southern Africa conference (ibid.) started to resonate with the political awareness of unprivileged social groups in a variety of contexts and geographical areas. Activists from disadvantaged communities such as the Khoisan or Khoe-San (non-Bantu people) began to investigate their colonial and precolonial past to find cultural specificity and uniqueness in support of identity claims. Inspired by Volkekunde scholarship, Khoe-San invested in an essentialized depiction of ethnicity (Verbuyst 2017 and Zenker 2016), in a process that has been qualified in other contexts as strategic essentialism, i.e., the reification of culture as a tool for overcoming discrimination and claiming political rights (Spivak 1996); and supporting arguments for the primacy of Indigenous expertise in matters of World Heritage (Meskell 2013).

The appropriation of Volkekunde to support self-determination rights is a theoretical and pragmatical development that is crucial to the understanding of the positionality of anthropologists engaging with law in South Africa. Similar to Spivak (1996), who introduced the concept of strategic essentialism based on the perspective of Indian subaltern groups willing to rewrite Indian history from "below," the reappropriated Volkekunde goes beyond reverse stigma and touches on the sources of anthropological expert knowledge. In fact, in legal cases that require the identification of cultural knowledge for the determination of land claims in South Africa, the reappropriation of Volkekunde comes with far-reaching dilemmas concerning the risk of reintroducing the classifications that supported discrimination. Spivak (1996) warned that strategic essentialism might lead to frozen identities and the perpetuation of inequalities. As Zenker (2016) states, given the interwoven linkage between South African anthropologies and colonial injustice, it seems rather difficult to identify the kind of anthropology that could serve to interpret the social context of land restitution. Yet, this does not mean that anthropological knowledge is per se unsuited to contributing to the resolution of land conflicts. A critical knowledge of the dynamics that favored white colonial dominance within anthropology as a discipline is crucial if one is to grasp the sociopolitical dynamics of contemporary South Africa (Waal and Ward 2006). Zenker $(2016,303)$ also argues that specifically in the South African 
context, it is possible to produce expertise if a certain consistency is achieved between what it is said and how it is said, leading to a strengthened ethical commitment.

In other words, what Spivak (1996) has theorized with the concept of strategic essentialism, and Zenker (2016) seems to develop concerning cultural expertise in South Africa, is that a strong link exists between cultural expertise and contextsensitive engagements that goes beyond politics to touch on notions of justice and social responsibility. The rise and fall of Volkekunde, as well as its recent reappropriation by underprivileged South African groups claiming the status of First People, show that a responsible engagement with law and governance requires a dynamic and multifaceted interpretation of the relationship between law and culture which is rooted in the observance of ethical codes of conduct but is also nurtured by a deep knowledge of the context. The combination of ethics and deep knowledge of the context appears therefore as the core of responsible cultural expertise which makes it possible to overcome, if needed, the constraints of theoretical positions. Yet, even admitting that, for the benefit of vulnerable groups, anthropologists will develop a higher standard of ethics which combines knowledge of the political and social context with explicit criticism of power structures, it remains to be seen if it is possible to also develop directions for a responsible positionality at times of unprecedented conflicts such as genocide. The next section will trace the relationship between the Rwandan genocide and anthropology to assess which directions of engagement may open up for anthropologists in situations of extreme vulnerability and tension.

\section{THE RWANDAN GENOCIDE}

Anthropologists' sense of displacement and awkwardness in the face of genocide is noted by Laban Hinton (2002), who endorses Clifford Geertz's feelings regarding the incapacity of anthropologists to engage with dramatic events so that they always arrive too early or too late (Geertz 1995). The reluctance of anthropologists to directly engage with topics of violence and genocide is dictated, according to Hinton, by their wish to avoid the branding of certain social groups as "primitives." However, Hinton's explanation is not entirely convincing in light of the ambiguous and eventually abhorrent role of Volkekunde in Africa because the history of apartheid shows an explicit justification of discrimination by Volkekunde. The questions regarding the positionality of anthropologists vis-à-vis the genocide in Rwanda are therefore: What was the relationship between anthropological theories and genocide in Rwanda; and why did anthropologists not come forward to contribute to avoiding the genocide in Rwanda?

The Rwandan genocide, which left between 800,000 and one million Rwandans dead in 1994, is regarded as an example of the horror caused by the translation of anthropological theories about race and displacement into nationalist ideology. The Hamitic theory, which connects the nineteenth-century explorers of Central Africa to the Belgian anthropologists of the 1930s, hypothesized that specific somatic traits coupled with the superior social role of the Tutsi over the Hutu were explained by the fact that the former came from a pastoral superior Caucasoid civilization whereas the latter were native agriculturalists. Belgian colonization of Rwanda started in 1912 and was granted legitimacy in 1919 by the League of Nations. Belgian settlers and 
colonial authorities subscribed to the belief of the racial superiority of Tutsi over Hutu and in 1933 anthropologists went to Rwanda to classify the population by phenotype following the classificatory principles of the phrenological science (André 2018).

The Belgian colonial power adopted an indirect rule mode of governance which empowered the Tutsi over the Hutu and introduced, in 1936, Native Tribunals headed by Tutsi chiefs (Jefremovas 1997). Between 1933 and 1997 the racial identity of Rwandan citizens was recorded on identity cards which, in 1994, became instrumental in the identification and killing of members of the opposing group. Hence, the collection of data by anthropologists and ethnologist-missionaries added a physical, measurable dimension to a loose concept of race, which entered the sociopolitical domain and found expression in governance and ultimately in genocide (Straus 2001). The colonizers read the imbalance of power between the two groups as the natural consequence of racial inequalities and developed a perspective which was also endorsed by the missionary churches and ultimately served the interests of Belgian colonial indirect governance (Gatwa 2000).

Whilst the conflict between Tutsi and Hutu existed before colonization, the racial classification of Tutsi as descending from Caucasoid "Hamites," and as such supposedly being closer to Europeans, was a key factor in Tutsi claims. German and Belgian administrators gave the Tutsi opportunities for education and important political and administrative privileges (Mamdani 2001). The Hutu were excluded from higher education and from administrative positions. Hence, an otherwise dynamic relationship was crystallized and the conditions for irretrievable tension between the two groups were created. Eventually, the concept of the different territorial origins of Hutu and Tutsi, which was also endorsed by major anthropologists like Charles Seligman (1930), provided an additional scientific foundation for the Hutu nationalist movement seeking a return to the pristine conditions of racial purity by orchestrating the mass murder of the Tutsi invaders.

The role of anthropologists and Christian missionaries in Rwanda, whose ideology and praxis stimulated and crystallized the two groups' roles, is still a haunting reminder of the colonizers' responsibilities in Rwanda's genocide (Touré 2013). Even though in the 1970s, a new generation of historians and anthropologists had already questioned the socioeconomic configuration suggested by previous anthropological studies, and had attempted to offer a more balanced picture of Rwandan society (Pottier 2002), the crystallization of the asymmetrical relation between Tutsi and Hutu in the anthropological theories of ethnicity was ingrained into colonial governance (Vidal 1991). The ideological divide embodied by divisive administrative practices such as the record of ethnicity on the identity cards of Rwandan citizens was so deeply rooted that the anthropological questioning of its historical legitimacy had little practical effect.

De Heusch (1995) not only poignantly described the perverse effects of nationalism and in particular the indiscriminate appropriation of anthropological knowledge by colonial and subsequent powers, which exacerbated ethnic rivalries leading to the Rwandan genocide, he also explicitly held Belgian anthropology responsible for unduly emphasizing the sociocultural dominance of the pastoral Tutsi over the agricultural Hutu. However, a reassessment of the responsibility for Rwandan genocide is not within the scope of this article. What I seek to scrutinize is the positionality of anthropological knowledge vis-à-vis the colonial enterprise with a view to understanding what kind of 
engagement anthropologists can take into consideration when providing expertise for governance.

Even though by the 1970s most anthropologists had already abandoned ill-informed classifications that supported discrimination and, in Rwanda, provided scientific support for genocide, the chain of both self-examination and blame seems to offer yet another instance of what Geertz $(1995,4)$ described as "the uncomfortable sense of having come too late and arrived too early." If one wanted to view the Rwanda genocide through Geertz's words, anthropologists arrived too early in the sense of incautiously engaging with a classification that would then serve the implementation of discriminatory practices and eventually lead to genocide, and too late because when they realized what was happening, they did not have the authority to amend the atrocious inequalities that these theories helped to consolidate.

Since the 1970s, the trends of critical anthropology have developed and fine-tuned the debate about power and social inequality by arguing that anthropologists have a duty to identify the causes and consequences of structural inequalities and poverty, including the deep scrutiny of local power relationships, which also shows how, in some cases, victims become persecutors (Farmer, Bourgois, Scheper-Hughes, Fassin, Green, Heggenhougen, Kirmayer, and Wacquant 2004). For Farmer (2004) anthropologists have a duty to make visible the social machinery of violence, inequality, and oppression that perpetuate structural inequalities, to contribute to identifying the ways in which correction can be achieved, and to fight against privilege. Fassin $(2004,319)$ goes even further to apply Farmer's exegesis to the historical experience and argues that "[a]lthough prediction is beyond the scope of anthropology ... political responsibility is directly involved in ethnographic work." I suggest that critical anthropology's call, and more specifically Fassin's argument of political responsibility, can be used to develop a renewed anthropological consciousness in the embodiment of history. Critical anthropology shows that inexcusable involvements, such as the one of classificatory theories in Rwanda, do not necessarily mean that anthropologists should cease engagement tout court, and suggests instead that anthropology is equipped to apprehend power by using its deep knowledge of the context in order to fight structural inequalities and discrimination.

\section{PROCEDURAL NEUTRALITY AND CRITICAL AFFIRMATION}

The new concept of cultural expertise considers the positionality of anthropologists vis-à-vis the judiciary and in a broad sense, the state, the government and the army, by stressing on one hand the independent role of anthropologists as experts who provide special knowledge and on the other hand their duty to the decision-making authority intended as the representative of the law. Cultural expertise as an umbrella concept has the potential to ethically translate, across a range of disciplines and sectors, cognate notions such as culturally motivated crimes and cultural defense, which have met with difficult implementation or potential misunderstanding. Among these is the potential causality between certain crimes and certain ethnicities. This was arguably unintended in the first conceptualization of culturally motivated crimes, and it is certainly against the ethics of anthropology and the deontology of cultural experts today. Cultural 
expertise takes explicit distance from discrimination and cultural determinism by relying on international human rights and the professional deontology of anthropology. However, the cases proposed by this article show that neither the law nor professional deontologies sufficiently ensure the sound positionality of anthropologists.

The Kenyan case highlights the risk of anthropological knowledge being incorporated today into supposedly culturally aware administrative and judiciary practices that in reality may coopt anthropology and anthropologists as instruments of dominance. According to Foks, Malinowski was able to benefit from colonial rule whilst resisting and challenging it from within. It is futile, in my view, to attempt an understanding of whether Malinowski really intended and was in the position to achieve social change at that time. History shows the ambiguity of his role, but what remains interesting for the analysis is Malinowski's reasoning on the ethical responsibilities of anthropologists. Contemporary modalities of the involvement of anthropologists with hegemonic institutions, such as armies and governments, are closely reminiscent of the significant, albeit ambiguous stance of Malinowski vis-à-vis the policies of indirect rule and suggest that the attempt to challenge inequality and discrimination from inside risks perpetuating the imbalance (Loperena, Mora, and Hernández-Castillo 2020).

The first success of Volkekunde in Africa, endorsing and justifying apartheid, and its twentieth century appropriation by minority groups in South Africa, show the subtlety and complexity of anthropological theories whose impact changes over time depending on the users. The same Volkekunde theories which have been abandoned by mainstream anthropology because of their direct link with discrimination in South Africa have been adopted to further the rights and affirm the political position of Khoe-San or non-Bantu people. Hence, the positionality of the anthropologist acquires another facet with the need not only to explicitly engage according to the ethics and deontology of the discipline, which have at several points been reaffirmed in the history of anthropology (Fluehr-Lobban 2003), but also translating the fluidity of anthropological theories thanks to a deep understanding of the contexts.

Still, it remains important to abstain also from engagement when this is a potential source of harm. The work of anthropologists who systematically classified people as belonging to either the Hutu or the opposing Tutsi in Rwanda created the basis on which relied the perpetrators of genocide in Rwanda. The analysis of the intricate web of responsibility for Rwanda's genocide, however, shows only too well that it would be superficial and naïve to blame anthropology and anthropologists alone. The translation of Geertz's sense of temporal displacement to the incapacity of anthropologists to act in time to avoid or attempt to avoid the Rwandan genocide suggests that it is not good enough to merely abstain from action. As Fassin (2004) says, anthropology and anthropologists cannot predict the future but are uniquely equipped with the capacity for a deep understanding of the social contexts. This unique capacity has the potential to be useful to foster a responsible cultural expertise.

This article shows that whilst ethics are paramount for the anthropologists engaging with cultural expertise, an accurate grasp of positionality is also necessary whenever structural power imbalance can instrumentalize anthropological knowledge. Examples also include the international protection of asylum seekers and migrants; the status of migrants in the countries of migration and the extent of the application of laws of the countries of origin; and the ascertainment of rights of First People, Indigenous 
communities, and other minority groups. Anthropologists acting as expert witnesses are required to be neutral and this potentially conflicts with their duty in favor of vulnerable groups and minorities affected by structural inequalities. Sometimes the settlement of conflicts and the ascertainment of rights does not happen in court but in out-of-court fora such as education, detention, and health centers as well as in alternative dispute resolution. For this reason, the reformulation of the definition of cultural expertise, which broadens the field of action of anthropologists so as to include nonstate jurisdictions, reiterates the primacy of the role of the decision-making authority. By saying that the duty of anthropologists is to the decision-making authority, a procedural distance is established with the parties to the process, i.e., the prosecution and the defense, which strengthens the ethical and deontological distance of the experts and allows for a more extended social responsibility.

With the concept of procedural neutrality, I intend to strengthen the academic nature of the concept beyond the court environment, but at the same time make space for the ethical engagement of social scientists with the legal process, positioning themselves responsibly to overcome the mere translation of facts into terms that are familiar to the decision-making authorities. Hence, the position of procedural neutrality itself requires rigorous scrutiny to avoid a generic legitimacy that may blur ambiguous allegiances. The neutrality of social scientists should neither be confused with the naïve objectivity that has been a longstanding issue in the social sciences (Letherby, Scott, and Williams 2013), nor should it be allowed to obscure the structural inequalities that also affect justice and legal procedures. The issue of positionality eventually translates into a larger question that has preoccupied positivists and post-positivists with the philosophy of law and the sociology of science: the legitimacy of law is based on the hierarchy of its sources and the incongruence which is inherent in the legal system itself because the legitimacy of the law is eventually self-referential.

Respectively from the legal and sociological perspectives, Kelsen (2005) in the first half of the twentieth century and Jasanoff (1997) toward the end of the twentieth century have both examined the self-referential character of law, the first by scrutinizing the legitimacy of the highest source of law which often exceeds positivist tenets, and the second by highlighting the influence of the formal language of law on the meanings of science and technology in people's everyday lives. Their analyses are both relevant for the positionality of the anthropologists who contemplate engagement with law and governance. How can we ensure that our engagement with the legal system is not informed by those very constraints and inequalities that, as anthropologists, we want to fight? I attempt a pragmatic solution that abides by the law that anthropologists must observe if we decide to engage, yet also permits much-needed criticism.

The procedural neutrality of cultural expertise refers to the position of the social scientists acting as experts who are critically affirming themselves as independent within the process of dispute resolution or claims of rights in court or out of court. Procedural neutrality is inspired by education studies on the one hand (Ashton and Watson 1998), and on the other by the experience of the anthropologists acting as expert witnesses. Two main positions have developed in the history of expert witnessing, which have acquired by now several ramifications but remain significant for the present study. On one hand Trigger and Good, with experience respectively as experts in Australia for native land rights and in the United Kingdom for international protection, show 
that experts who adopt an advocacy role in court are likely to be revoked and do not benefit the very people whom anthropologists are expected to support and protect (Trigger 2004; Good 2007). On the other hand, Campbell (2020), with equivalent experience as an expert in the United Kingdom's immigration tribunals, citing Jones (1994) and Redmayne (2001), denounces the cooptation of anthropologists by the legal system. He says that immigration judges tend to see experts as an obstacle and, no matter their efforts to be neutral, they remain prone to see experts as advocates for the applicants (Campbell 2020).

This article argues that the positionality of anthropologists today, despite considerable strengthening of the deontological codes of the discipline of anthropology, is subject to similar vulnerabilities to those observed in the Kenyan case where Malinowski attempted perhaps to challenge the system from inside but remained substantially ambiguous vis-à-vis dominant power structures. If we accept a loose analogy between the position of the teacher and that of the anthropologist acting as an expert witness, procedural neutrality is enriched by yet another nuance. Education studies have further developed the approach of procedural neutrality to say that the role of the teacher who conventionally claims procedural neutrality is shifting toward critical affirmation that allows for a position to be argued that is itself subject to scrutiny thereby empowering students in the process of learning (Ashton and Watson 1998). Similarly, procedural neutrality, in the context of cultural expertise, refers to the capacity of anthropologists to carve out a place for themselves in the legal process, or more broadly in the process leading to the decision, also including arguments for the primacy of Indigenous expertise and the denunciation of structural inequalities. It is in fact possible to shift toward critical affirmation when anthropologists who act and are perceived as acting in a procedurally neutral way, provide information that is subject to the scrutiny of the decision-making authorities yet carries a significant potential of empowerment for the parties whose rights are undermined by structural inequalities. In other words, anthropologists who adopt a position of procedural neutrality have the potential to empower vulnerable groups without contradicting the ethics and deontologies of the disciplines across which they operate.

\section{CONCLUSION}

This article partially confirms the hypothesis that the initial complicity of anthropology in the colonial agenda related to the lack of independence of anthropologists, as in the Kenyan case. But the development of anthropological theories that conflicted with the ethical tenets of the discipline as in the ethnic classification used by colonizers in Rwanda and in the Volkekunde takes us further, toward a potential conclusion on the incommensurability of anthropology with law and governance. This article elucidates two additional kinds of criticism regarding the involvement of anthropologists: the unethical cooptation of anthropologists by the state, and the responsibility arising from involvement as much as from noninvolvement. These all point to a difficult positionality for the anthropologists who engage with law and governance, and the need to adequately consider power as a variable in its engagement with law. Visweswaran (2004) significantly criticizes the political involvement of minorities in action that 
was favorable to a social cause but was in fact detrimental to their everyday individual lives. As Zenker $(2016,304)$ says "when positioning ourselves theoretically, we also have to take pre-emptive responsibility for the potential theory effects that are likely to follow from our own theoretical stances." I argue that whilst the responsibility of anthropologists and anthropology is irrefutable in the cases of collaboration with colonizers, cooptation and cooperation with imperialist and neocolonial agendas, the way out is not so much by proclaiming the incapacity of the discipline to engage with law as by a carefullythought-out ethical theorization of what such an engagement should be.

Alternative theoretical frameworks, such as critical anthropology (Farmer 2004), as well as the anthropology of human rights (Goodale 2009; 2017), and recursive anthropology (Franklin 2013; Zenker 2016) offer new platforms on which to develop new conceptual frameworks such as cultural expertise and to fine-tune anthropological positionality such as procedural neutrality with a potential shift toward critical affirmation. These new conceptual tools may provide the answer to the criticism historically affecting anthropology and the engagement of anthropologists with law. Anthropologists can become agents of resistance if we are able to adopt a stance which abides by the law yet is independent enough to work with the legal professions without being coopted by the judiciary or the government. Social scientists who are ready to bypass the frequently unresolved opposition that has polarized sociolegal scholarship (state law versus nonstate law, legal systems versus normative orders, and observation versus participation) can adopt a position of procedural neutrality enhanced by critical affirmation to explore a responsible engagement with cultural expertise. Thus, the positioning of cultural experts, for a responsible and ethical engagement with law and the ascertainment of rights, might indeed be the theoretical framework that allows scholars to ethically theorize the use of social sciences in policymaking, international relations, dispute resolutions, and claims of rights by Indigenous people as well as ethnic, religious, and social minorities, and more broadly in intercultural communication.

\section{SOURCE OF FUNDING}

This is a primary output of EURO-EXPERT project no. 681814 funded by the European Research Council.

\section{REFERENCES}

André, Charles. "Phrenology and the Rwandan Genocide." Arquivos De Neuro-psiquiatria 76, no. 4 (2018): 277-82.

Asad, Talal. Anthropology $\mathcal{E}$ the Colonial Encounter. London: Ithaca Press, 1973.

Ashton, Elizabeth, and Brenda Watson. "Values Education: A Fresh Look at Procedural Neutrality." Educational Studies 24, no. 2 (1998): 183-93.

. "Values Education: A Fresh Look at Procedural Neutrality." Educational Studies 24, no. 2 (1998): $183-93$.

Bank, Andrew. "The Berlin Mission Society and German Linguistic Roots of Volkekunde: The Background, Training and Hamburg Writings of Werner Eiselen, 1899-1924." Kronos (Bellville, South Africa) 41, no. 1 (2015): 166-97. 
Bartoli, Clelia. "Terrorismo o Resistenza? Il Processo di Napoli." In Oltre la Nazione. Conflitti Postcoloniali e Pratiche Interculturali. Il Caso della Diaspora Tamil. Edited by Giuseppe Burgio, 79-98. Roma: Ediesse, 2014.

Basile, Fabio. "Il Diritto Penale Nelle Società Multiculturali: I Reati Culturalmente Motivati." Política Criminal 6, no. 12 (2011): 339-86.

Burdziej, Stanisław. "Judging the Communist Past: Historians and Cultural Expertise in Polish Administrative Courts". Law and History Review 38, no. 1 (2020): 99-122.

Campbell, John R. "The Role of Lawyers, Judges, Country Experts and Officials in British Asylum and Immigration Law." International Journal of Law in Context, 16, no. 1 (2020): 1-16.

Ciccozzi, Antonello, and Giorgia Decarli. "Cultural Expertise in Italian Courts: Contexts, Cases, and Issues." In Cultural Expertise and Socio-legal Studies. Edited by Livia Holden, 35-55. Bingley, UK: Emerald Insight, 2019.

Colajanni, Antonino. “Pure' and 'Applied' Research. Theoretical and Applied Anthropology a Decade after the Beginning of the Third Millennium." DADA Rivista di Antropologia Post-globale 2 (2014): 25-40.

Cooke, Taina. "From Invisible to Visible: Locating "Cultural Expertise" in the Law Courts of Two Finnish Cities." In Cultural Expertise and Socio-Legal Studies. Edited by Livia Holden, 13-33. Bingley, UK: Emerald Insight, 2019.

De Heusch, Luc. "Rwanda: Responsibilities for a Genocide." Anthropology Today 11, no. 4 (1995): $3-7$.

Diamond, Stanley. "A Revolutionary Discipline." Current Anthropology 5, no. 5 (1964): 432-37.

—. "The End of the First Republic." Africa Today 13, no. 2 (1966): 5-9.

Evans, Ivan Thomas. Bureaucracy and Race: Native Administration in South Africa. Berkeley, CA: University of California Press, 1997.

Farmer, Paul, Bourgois, Philippe, Scheper-Hughes, Nancy, Fassin, Didier, Green, Linda, Heggenhougen, H, Kirmayer, Laurence, and Wacquant, Loïc. "An Anthropology of Structural Violence." Current Anthropology 45, no. 3 (2004): 305-25.

Fluehr-Lobban, Carolyn. Ethics and the Profession of Anthropology: Dialogue for Ethically Conscious Practice. $2^{\text {nd }}$ ed. Walnut Creek, CA; Oxford: Altamira, 2003.

Foblets, Marie-Claire, and Alison Dundes Renteln. Multicultural Jurisprudence: Comparative Perspectives on the Cultural Defense. Oxford; Portland, OR: Hart Publishing, 2009.

Foks, Freddy. "Bronislaw Malinowski, 'Indirect Rule,' and the Colonial Politics of Functionalist Anthropology, ca. 1925-1940." Comparative Studies in Society and History 60, no. 1 (2018): 35-57.

Franklin, Sarah. "In Vitro Anthropos: New Conception Models for a Recursive Anthropology?" Cambridge Anthropology 31, no. 1 (2013): 3-32.

Gatwa, Tharcisse. "Mission and Belgian Colonial Anthropology in Rwanda. Why the Churches Stood Accused in the 1994 Tragedy? What Next?" Studies in World Christianity 6, no. 1 (2000): 1-20.

Geertz, Clifford. After the Fact: Two Countries, Four Decades, One Anthropologist. Jerusalem-Harvard Lectures. Cambridge, MA; London: Harvard University Press, 1995.

Good, Anthony. Anthropology and Expertise in the Asylum Courts. Abingdon, UK: Routledge Cavendish, 2007.

Goodale, Mark. Surrendering to Utopia: An anthropology of human rights (Stanford Studies in Human Rights). Stanford, CA: Stanford University Press, 2009.

Goodale, Mark, and Sally Engle Merry. Anthropology and Law: A critical introduction. New York, 2017.

Gordon, Robert. "Anthropology and Apartheid - the Rise of Military Ethnology in South Africa." Cultural Survival Quarterly (1981-1989) 11, no. 4 (1987): 58.

. "Apartheid's Anthropologists: The Genealogy of Afrikaner Anthropology." American Ethnologist 15, no. 3 (1988): 535-53.

—. "How Good People Become Absurd: J.P. van S. Bruwer, the Making of Namibian Grand Apartheid and the Decline of Volkekunde." Journal of Southern African Studies 44, no. 1 (2018): 97-113.

Grillo, Ralph. "Anthropologists Engaged with the Law (and Lawyers)." Antropologia Pubblica 2, no. 2 (2016): 3-24. 
Hinton, Alexander Laban. Annihilating Difference: The Anthropology of Genocide. Berkeley, CA; University of California Press, 2002.

Holden, Livia. Cultural Expertise and Litigation: Patterns, Conflicts, Narratives. Milton Park, Abingdon, Oxon, UK; New York: Routledge, 2011.

- Cultural Expertise and Socio-Legal Studies. Studies in Law, Politics and Society. Bingley, UK: Emerald Insight, 2019.

—. "Cultural Expertise and Law: An Historical Overview." Law and History Review 38, no. 1 (2020): 29-46.

James, Deborah. "David Webster: An Activist Anthropologist Twenty Years On." African Studies: Religion and Migration 68, no. 2 (2009): 287-95.

Jasanoff, S., \& JASANOFF, S. Science at the bar : Law, science, and technology in America : law, science, andtechnology in America. Cambridge, MA: Harvard University Press, 1997.

Jasanoff, Sheila. Science at the Bar: Law, Science, and Technology in America. Cambridge, MA: Harvard University Press, 1995.

Jefremovas, Villia. "Contested Identities: Power and the Fictions of Ethnicity, Ethnography and History in Rwanda." Anthropologica 39, nos. 1/2 (1997): 91-104.

Johnson, W.R. (1982), Education: Keystone of Apartheid. Anthropology E Education Quarterly, 13: 214-237

Jones, Carol. Expert Witnesses. Science, Medicine and the Practice of Law. Oxford: Clarendon Press, 1994.

Jordan, Winthrop D. White over Black: American Attitudes toward the Negro, 1550-1812. Chapel Hill, NC: University of North Carolina Press, 1968.

Kelsen, Hans. Pure Theory of Law. Clark, NJ: Lawbook Exchange, 2005.

Letherby, Gayle, John Scott, and Malcolm Williams. Objectivity and Subjectivity in Social Research. Objectivity and Subjectivity in Social Research. London: SAGE Publications Ltd., 2013.

Loperena, Christopher, Mariana Mora, and R. Aída Hernández-Castillo. "Cultural Expertise? Anthropologist as Witness in Defense of Indigenous and Afro-Descendant Rights." American Anthropologist 122, no. 3 (2020): 588-94.

Lopes, João Teixeira, Anabela Costa Leão, Lígia Ferro, "Assessing Cultural Expertise in Portugal: Challenges and Opportunities." In Cultural Expertise and Socio-Legal Studies. Edited by Livia Holden, 57-74. Bingley, UK: Emerald Insight, 2019.

Luongo, Katherine. Witchcraft and Colonial Rule in Kenya, 1900-1955. Cambridge, UK: Cambridge University Press, 2011.

Malinowski, Bronisław, and Norbert Guterman. A Diary in the Strict Sense of the Term. London: Routledge, 2004.

Mamdani, Mahmood. When Victims Become Killers: Colonialism, Nativism, and the Genocide in Rwanda. Princeton, NJ; Oxford: Princeton University Press, 2001.

Maquet, Jacques. "Objectivity in Anthropology.” Current Anthropology 5, no. 1 (1964): 47-55.

Marin, Soudabeh. "Cultural Expertise in Iran: From the Pahlavi Dynasty to Contemporary Diasporas." Law and History Review 38, no. 1 (2020): 75-84.

Memmi, Albert. Dominated Man. Boston: Beacon Press, 1969.

Memmi, Albert, and Howard Greenfeld. The Colonizer and the Colonized. Boston: Beacon Press, 1967.

Meskell, Lynn. "UNESCO and the Fate of the World Heritage Indigenous Peoples Council of Experts (WHIPCOE)." International Journal of Cultural Property 20, no. 2 (2013): 155-74.

Pottier, Johan. Re-imagining Rwanda: Conflict, Survival and Disinformation in the Late Twentieth Century. Cambridge: Cambridge University Press, 2002.

Redmayne, Mike. Expert Evidence and Criminal Justice. Oxford: Oxford University Press, 2001.

Renteln, Alison Dundes. The Cultural Defense. Oxford: Oxford University Press, 2004.

Rosen, Lawrence. "Expert Testimony in the Social Sciences: A Historical Overview of Contemporary Issues." Law and History Review 38, no. 1 (2020): 123-42.

Ruggiu, Ilenia. Culture and the Judiciary: The Anthropologist Judge. $1^{\text {st }}$ ed. London: Routledge, 2019.

Seligman, Charles G. Races of Africa. London: Thornton Butterworth, 1930.

Seroto, Johannes. "A Revisionist View of the Contribution of Dr Eiselen to South African Education: New Perspectives." Yesterday and Today 9 (2013): 91-108. 
Spivak, Gayatri. “Subaltern Studies: Decon- structing Historiography?" In he Spivak Reader, edited by Donna Landry and Gerald MacLean, 203-237. London: Routledge, 1996.

Straus, Scott. "Organic Purity and the Role of Anthropology in Cambodia and Rwanda." Patterns of Prejudice 35, no. 2 (2001): 47-62.

Strijbosch, Fons. "Culturele delicten in de Molukse gemeenschap." Nederlands Juristenblad (1991): 666-72.

Touré, El Hadj. "Beyond the Political Causes of the Rwandan Genocide: A Historical and Sociocultural Construction of Ethnicity." Déviance et Société 37, no. 4 (2013): 463-85.

Trigger, David. "Anthropology in Native Title Cases: Mere Pleading, Expert Opinion or Hearsay?" In Crossing Boundaries: Cultural, Legal Historical and Practice Issues in Native Titles. Edited by S. Toussaint. Melbourne: Melbourne University Press, 2004.

Van Broeck, Jeroen. "Cultural Defence and Culturally Motivated Crimes (Cultural Offences)." European Journal of Crime, Criminal Law and Criminal Justice 9, no. 1 (2001): 1-32.

Verbuyst, Rafaël. "Layered Decolonization in South Africa: Khoisan Strategic Essentialism and the Notion of Incommensurability." Paper presented at the $4^{\text {th }}$ International Indigenous Voices in Social Work Conference, June 12-15, 2017, Alta, Norway.

Vidal, Claudine, and Georges Balandier. Sociologie Des Passions: Rwanda, Côte D'Ivoire. Paris: Karthala, 1991.

Visweswaran, Kamala. "Gendered States: Rethinking Culture as a Site of South Asian Human Rights Work." Human Rights Quarterly 26, no. 2 (2004): 483-511.

- Un/Common Cultures: Racism and the Rearticulation of Cultural Difference. Durham, NC: Duke University Press, 2010.

Waal, Cees S., and Vivienne Ward. "Shifting Paradigms in the New South Africa: Anthropology after the Merger of Two Disciplinary Associations." Anthropology Today 22, no. 1 (2006): 17-20.

Woodman, Gordon R. "The Culture Defence in English Common Law: The Potential for Development." In Multicultural Jurisprudence: Comparative Perspectives on the Cultural Defense. Edited by Marie-Claire Foblets and Alison Dundes Renteln. London: Hart Publishing, 2009: 7-34.

Zenker, Olaf, "Anthropology on Trial: Exploring the Laws of Anthropological Expertise." International Journal of Law in Context 12, no. 3 (2016): 293-311. 